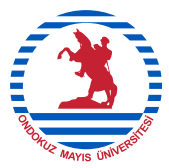

\title{
The Effect of Obesity Education on the
} Knowledge Levels of Women Applying to A Primary Health Care Center

\author{
Birinci Basamak Sağlık Merkezine Başvuran \\ Kadınlarda Obezite Eğitiminin Bilgi Düzeyleri Üzerine \\ Etkisi
}

Leyla TÜRKER DEMIRKAN', Hasret YALÇINÖZ BAYSAL ${ }^{2}$, Recep ÖZKAN³

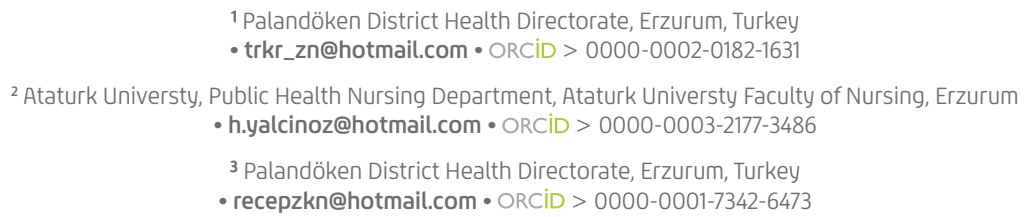

Makale Bilgisi / Article Information

Makale Türü / Article Types: Araştırma Makalesi / Research Article

Geliş Tarihi / Received: 1 Nisan/ April 2021

Kabul Tarihi / Accepted: 5 Mayıs / May 2021

Yil/Year: 2021 | Cilt -Volume: 6 | Sayl-Issue: 2 | Sayfa/Pages: 331-344

Atıf/Cite as: Türker Demirkan, L., Yalçınöz Baysal, H. ve Özkan, R. “The Effect of Obesity Education On The Knowledge Levels of Women Applying To A Primary Health Care Center - Birinci Basamak Sağlık Merkezine Başvuran Kadınlarda Obezite Eğitiminin Bilgi Düzeyleri Üzerine Etkisi". Samsun Sağık Bilimleri Dergisi- Journal of Samsun Health Sciences 6(2), Ağustos 2021:

331-344. https://doi.org/10.47115/jshs.908167

Sorumlu Yazar: Hasret YALÇINÖZ BAYSAL

Copyright @ Published by Ondokuz Mayıs Üniversitesi, Sağlık Bilimleri Fakültesi - Ondokuz Mayıs University, Faculty of Health Sciences, Samsun, Turkey. All rights reserved. 


\section{THE EFFECT OF OBESITY EDUCATION ON THE KNOWLEDGE LEVELS OF WOMEN APPLYING TO A PRIMARY HEALTH CARE CENTER}

\section{ABSTRACT:}

Aim: This study was conducted to measure the effect of education given to women on obesity on their level of knowledge.

Method: This research was performed as a single group pretest-posttest quasi-experimental design between June 2019 and January 2020. Women $(n=200)$ between the ages 20-64 affiliated to a District Health Directorate in Turkey were selected from registered family health centers. Women's received an average of 60 minutes of obesity training for one session in total. Number, percentage and McNemar tests were used for the data calculation.

Results: It was determined that there is a significant increase between the knowledge levels of women before and after the education $(\mathrm{p}<0.05)$.

Conclusion and Suggestions: Education provided by health professionals on obesity was shown to be effective. Health training on prevention and management of obesity in primary care should be a fundamental component of health services. It is recommended that the training should be community-based and targeting the risk groups, as well as including interventions for primary and secondary prevention.

Keywords: Obesity; Knowledge level; Training; Primary care

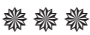 \\ BİRINCI BASAMAK SAĞLIK MERKEZINE BAŞVURAN KADINLARDA OBEZITE EĞiTIMININ BİLGi DÜZEYLERI ÜZERINE ETKISI}

ÖZ:

Amaç: Bu çalışma, kadınlara obezite konusunda verilen eğitimin, onların bilgi düzeyleri üzerine etkisini ölçmek amacıyla yapılmıştır.

Yöntem: Bu araştırma, Haziran 2019-Ocak 2020 tarihleri arasında tek gruplu ön test-son test yarı deneysel desen olarak gerçekleştirilmiştir. Türkiye’de bir İlçe Sağlık Müdürlügü̈ne bağlı 20-64 yaş arasındaki kadınlar (n=200), aile sağlığı merkezlerinin kayıtlarından seçilmiştir. Kadınlar toplam 1 seans için ortalama 60 dakika obezite eğitimi aldılar. Veri hesaplamasında sayı, yüzde ve McNemar test- 
leri kullanıldı.

Bulgular: Kadınların eğitim öncesi bilgi düzeyleri ile eğitim sonrası bilgi düzeyleri arasında anlamlı derecede yükselme olduğu belirlenmiştir $(\mathrm{p}<0.05)$.

Sonuç ve Öneriler: Sağlık çalışanlarının obezite konusunda verdiği eğitimin etkili olduğu saptanmıştır. Sağlık eğitimi birinci basamakta obezitenin önlenmesi ve yönetimi konusunda, sağlık hizmetlerinin temel bir bileşeni olmalıdır. Eğitimin toplum temelli olması, risk gruplarını hedeflemesinin yanı sıra birincil ve ikincil önleme için müdahaleleri de içermesi önerilir.

\section{Anahtar Kelimeler: Obezite; Bilgi düzeyi; Eğitim; Birinci basamak}

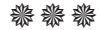

\section{INTRODUCION}

Today, obesity presents a public health problem that is increasing all around the globe. Obesity is defined as abnormal or excessive fat accumulation that poses a health risk. According to the data of the World Health Organization (WHO); about 2 billion of adults around the world are overweight and more than half a billion are obese. In 2016, 39\% of both men and women were overweight, while $11 \%$ of men and $15 \%$ of women were obese. According to WHO data (2016) obese adult population in Turkey was $32.1 \%$ (24.4\% men, 39.2\% women), and based on gender, women is reported to present higher rates of being obese (WHO, 2020).

Being overweight and obese presents risk for developing non-infectious diseases such as cardiovascular diseases, diabetes, hypertension and cancer (Türkiye Endokrinoloji ve Metabolizma Derneği, 2014; WHO, 2020). Republic of Turkey, Ministry of Health National Burden of Disease study reported 88 percent of deaths in Turkey as a result of non-infectious diseases (Ulusal Hastalık Yükü Çalışması, 2019). Obesity not only causes physical diseases, but also causes social and mental problems and negatively affects the lifespan and quality of life. Therefore, it is more rational to take measures to prevent obesity (Latner et al., 2014; O'Biren et al., 2016). To take preventive measures for the whole society and risk groups, to make a habit of adequate and balanced nutrition, to give information and raise awareness through health education promoting regular exercise and maintaining normal body weight present crucial activities in this context (TC Saglık Bakanlıgı, 2010). Healthcare personnel in primary care have critical responsibilities in the fight against obesity, especially via health education (Tedik, 2017). In all of the studies conducted with various training periods and methods, it has been noted that there is a significant decrease in the obesity parameters of the patients after 
receiving training (Alıcı \& Pınar, 2008; Redmon et al., 2005; Sertöz \& Mete, 2005; Womble et al., 2004). It is very important for women to have sufficient information about obesity in prevention and struggle against obesity. Currently there is no study investigating the level of knowledge about obesity in Turkey.

In this study, we aimed to measure the effect of education given to women on obesity on their level of knowledge.

Hypothesis: H1. The education provided increases the knowledge level of women compared to the pre-education level of knowledge.

\section{METHOD}

\section{Study Design}

This research was performed as a single group pretest-posttest quasi-experimental study between June 2019 and January 2020.

\section{Participants and Recruitment}

The sample of the study consists of 20-64 years old women affiliated to a District Health Directorate. The sample consisted of 200 women's who were registered in family health centers which were selected by simple random sampling method from the units affiliated to this directorate and the sample size were determined by power analysis, in accordance with the sample selection criteria. Women's who were literate, did not have any psychological diseases that would prevent participation in education and volunteered to be in the study were included in the study.

\section{Intervention}

Participants received an average of 60 minutes of obesity training for one session in total. After the ethics committee and institutional permissions were obtained, the family health centers registered under the District Health Directorate were informed by the researchers about the study. Women registered to the family health centers were randomly selected from the list and called by phone, and those who met the inclusion criteria were informed about the training day and invited to the District Health Directorate.

The training sessions were held in the seminar class in the institution. Until the sufficient number of participants was reached, 20 people on average per group were trained, and training was given to different groups 2 days a week so as not to disrupt the workflow. 
After obtaining the consent of women who accepted to participate in the study, first their body mass index was calculated by the researchers by measuring their height and weight. Then, the pre-training test prepared by the researchers, in which sociodemographic characteristics and their knowledge about obesity were evaluated, was filled by the participants. The training was provided by the researcher with active participation once for 1 hour in duration, together with a slide show. In the training, the definition of obesity, it's prevalence in the world and in our country, the causes of obesity, treatment methods, and its relation with chronic diseases are explained. Participants were also given the opportunity to ask questions with active participation. Healthy Life Centers were also introduced during the training. The participating women were informed about the centers and encouraged to visit the centers whenever necessary. After the training, the measurement was repeated and the final test was applied. The training sessions were completed in approximately 4 months.

\section{Data Collection}

The data of the study were collected by the researchers via face-to-face interview technique between August 2019- November 2019. The questionnaire form was prepared by the researchers in accordance with the previous literature (Alicl \& Pınar, 2008; Redmon et al., 2005; Sertöz \& Mete, 2005; Womble et al., 2004). The questionnaire form contained 32 questions in total, including 13 questions on the socio-demographic characteristics of women and 19 questions about information on obesity. In the post-training test, there are a total of 17 questions including the 19 questions that measure the knowledge status of the pre-training test and also 4 additional questions to get feedback from women about the training on obesity. The data were collected just before and after the training, lasting in an average of 15 minutes each.

\section{Data Analysis}

Data obtained from the study were analyzed using SPSS 20 package programming on the computer. Descriptive statistics were reported as means \pm standard deviations and medians (interquartile ranges), and comparative statistics were performed using the related-samples McNemar test. All comparative tests were 2 -tailed, and $\mathrm{p}=.05$ was set as the threshold for statistical significance.

\section{Ethical Principles}

Ethics committee approval from Blinded Ethics Committee (date: 30.05.2019 and number: B.30.2.ATA.0.01.00/238) and official permission from the institution where the research was conducted were obtained. Before the data of the research 
is started to be collected, individuals are given information about the research in detailed and atttention has been paid to the ethical principles of "volunteering" "respect for autonomy", "informed consent", "confidentiality and protection of confidentiality" was followed throughout the research.

\section{RESULTS}

In our study, the avarage age of 200 women, 156 of whom were married (78\%), was $41.64 \pm 12.74$ years. While 122 of the women (61\%) have at least one chronic disease that did not prevent participation in education; $56 \%$ of them stated that they received medication for these diseases. The socio-demographic characteristics of the participants are presented in Table 1.

\begin{tabular}{|c|c|c|c|}
\hline & & $\mathbf{n}$ & $\%$ \\
\hline \multirow{2}{*}{ Mariatal status } & Married & 156 & 78.00 \\
\hline & Single/Divorced/Widowed & 44 & 22.00 \\
\hline \multirow[t]{4}{*}{ Educational level } & Primary school & 58 & 29.00 \\
\hline & Elementary school & 28 & 14.00 \\
\hline & High school & 63 & 31.50 \\
\hline & University or above & 51 & 25.50 \\
\hline Working out of home & & 63 & 31.50 \\
\hline \multirow{4}{*}{ Income status } & $\leq 2020 €$ & 95 & 47.50 \\
\hline & $2020-4040$ ま & 62 & 31.00 \\
\hline & $4040-6500$ ま & 40 & 20.00 \\
\hline & $>6500$ ま & 3 & 1.50 \\
\hline \multicolumn{4}{|l|}{ Smoking status } \\
\hline \multicolumn{2}{|l|}{ Yes } & 78 & 39.00 \\
\hline \multicolumn{2}{|l|}{ No } & 122 & 61.00 \\
\hline \multicolumn{2}{|l|}{ Comorbid disease } & 122 & 61.00 \\
\hline & HT & 42 & 21.00 \\
\hline & $\mathrm{DM}$ & 45 & 22.50 \\
\hline & Thyroid disease & 39 & 19.50 \\
\hline & Hyperlipidemia & 29 & 14.50 \\
\hline & Other chronic diseases & 31 & 15.50 \\
\hline \multicolumn{2}{|c|}{ Use of medication for chronic diseases } & 112 & 56.00 \\
\hline & & $\mathrm{X} \pm \mathrm{SS}$ & Min-Max \\
\hline \multicolumn{2}{|l|}{ Age (years) } & $41.64 \pm 12.74$ & $20-64$ \\
\hline \multicolumn{2}{|l|}{ Number of children } & $2.28 \pm 1.72$ & $0-7$ \\
\hline \multicolumn{2}{|l|}{ BMI $\left(\mathrm{kg} / \mathrm{m}^{2}\right)$} & $27.52 \pm 5.53$ & $17.5-38.2$ \\
\hline \multicolumn{2}{|l|}{ Waist circumference $(\mathrm{cm})$} & $83.21 \pm 14.59$ & $60-130$ \\
\hline
\end{tabular}


Participants were asked several questions about obesity both before and after the training. A significant increase was present in the overall level of knowledge after the training $(\mathrm{p}<0.001)$ (Table 2$)$.

\section{Table 2. The participants' true answers about obesity and related factors $(n=200)$}

\begin{tabular}{|l|c|c|c|c|c|} 
& \multicolumn{2}{|c|}{$\begin{array}{c}\text { Before } \\
\text { Education }\end{array}$} & \multicolumn{2}{c|}{$\begin{array}{c}\text { After } \\
\text { Education }\end{array}$} & \multirow{2}{*}{$\mathbf{p}^{*}$} \\
\cline { 2 - 5 } & $\mathbf{n}$ & $\mathbf{n}$ & $\mathbf{n}$ & $\%$ & \\
\hline Obesity is a disease & 158 & 79.00 & 200 & 100.00 & $<0.001$ \\
\hline Obesity prevalance is increasing in Turkey & 109 & 54.50 & 200 & 100.00 & $<0.001$ \\
\hline Diagnosis of obesity & 60 & 30.00 & 180 & 90.00 & $<0.001$ \\
\hline $\begin{array}{l}\text { The incidence of cardiovascular diseases increase in the pre- } \\
\text { sence of obesity }\end{array}$ & 115 & 57.50 & 197 & 98.50 & $<0.001$ \\
\hline Obese people are more prone to hypertension & 170 & 85.00 & 197 & 98.50 & $<0.001$ \\
\hline Fertiliy of obese women decrease & 42 & 21.00 & 163 & 81.50 & $<0.001$ \\
\hline $\begin{array}{l}\text { Breathing difficulties and snoring in sleep increase with obe- } \\
\text { sity }\end{array}$ & 87 & 43.50 & 195 & 97.50 & $<0.001$ \\
\hline $\begin{array}{l}\text { The risk of developing gallstones increases in the presence of } \\
\text { obesity }\end{array}$ & 65 & 32.50 & 195 & 97.50 & $<0.001$ \\
\hline The risk of calcification of knee joints increases with obesity & 142 & 71.00 & 196 & 98.00 & $<0.001$ \\
\hline The risk of breast cancer decrease in obese people & 26 & 13.00 & 177 & 88.50 & $<0.001$ \\
\hline The risk of fatty liver increase in the presence of obesity & 132 & 66.00 & 196 & 98.00 & $<0.001$ \\
\hline Frequency of depression increases with obesity & 73 & 36.50 & 178 & 89.00 & $<0.001$ \\
\hline $\begin{array}{l}\text { It is possible to prevent and treat obesity by making lifestyle } \\
\text { changes }\end{array}$ & 123 & 61.50 & 189 & 94.50 & $<0.001$ \\
\hline
\end{tabular}

${ }^{\star}$ McNemar Test

According to the feedback about the given training, $96.5 \%$ of the participants stated that the training was beneficial, $65.5 \%$ wanted to participate in different trainings about obesity, $92.5 \%$ thought to make a lifestyle change after this training, $77.0 \%$ stated that they will consider getting support from the Healthy Living Centers to make a change in lifestyle (Table 3 ).

\section{Table 3. The participants' feedback on obesity training and HLCs $(n=200)$}

\begin{tabular}{|l|c|c|}
\hline \multicolumn{2}{|c|}{ n } & \% \\
\hline Obesity training was beneficial & 193 & 96.50 \\
\hline I would like to participate in different trainings on obesity & 131 & 65.50 \\
\hline Thinking about making a lifestyle change after this training & 185 & 92.50 \\
\hline Yes & 15 & 7.50 \\
\hline No & 154 & 77.00 \\
\hline Consideration to seek support from Healthy Living Centers to make a lifestyle change & 46 & 23.00 \\
\hline Yes & 4 \\
\hline No & &
\end{tabular}




\section{DISCUSSION}

Obesity and associated socio-demographic parameters have been examined by many studies in the literature as well as this study. There are studies that found that the rate of obesity is higher in married women ( $\mathrm{p}<0.05)$ (Çayır et al., 2011; Maskarinec et al., 2006); obesity rate increases with higher age or when the number of children increases (Ayar, 2009), and that obesity is more common in women that are housewives and people with low income (Çayır et al., 2011). In the same studies, the rate of obesity in smokers was found to be less than those who did not smoke and quit smoking, thus it was concluded that smoking reduces the appetite $(\mathrm{p}<0.05)$ (Çayır et al., 2011; Maskarinec et al., 2006). In our study before the training, the average age was found similar to those previous studies; the proportion of those with high school or higher education and those with a lower education level was found to be approximately equal, and the rate of housewives or those with low income who had a higher risk of developing obesity was higher.

In a meta-analysis study on the prevalence of obesity in our country; the average BMI of the adult population was found as $25-29.9 \mathrm{~kg} / \mathrm{m} 2(28.0 \mathrm{~kg} / \mathrm{m} 2$ for women, $26.5 \mathrm{~kg} / \mathrm{m} 2$ for men); and similar results were obtained for the BMI value in our study (Ural, 2018). The rate of obese among the participants was found to be $27 \%$, which is similar to WHO data (Çayır et al., 2011). While the average waist circumference of women was calculated as $89.7 \mathrm{~cm}$ and the rate of abdominal obesity as $51 \%$ in six studies performed in our country, this value was found partially lower in our results. However, this value is higher than the upper limit values recommended by the International Diabetes Federation (IDF) for European, Eastern Mediterranean and Middle Eastern populations (Ural et al., 2015).

The main purpose of our study was to train the participants about obesity in a cause and effect association and with its complications in detail to raise awareness. In order to evaluate this, questions about obesity were asked before and after the training to measure the change in knowledge level and a statistically significant increase was found for the number of correct answers to all questions. The main reason for this finding was probably as a result of the low rate of participants receiving training about obesity before. However, pre-training answers of the patients showed that half of the participants were aware that there is a healthy life center near their home and half of the participants have applied to a healthy life center and dietician at least once, obesity was accepted as a disease, its rate is increasing day by day in our country and obesity can be prevented with lifestyle changes. These were answered correctly in the pretest by most of the participants. There are very few similar studies in the literature measuring the level of knowledge about obesity and related complications in our country. In a study, the rate of those who defined obesity as a disease was $92.6 \%$, and the rate of those who knew that it was 
determined by measuring height and weight was $61 \%$, and the level of knowledge of the participants was higher than in our study (Ayar, 2009). Contrary to what was expected in our study, the rate of compliance with the given diet and reaching the desired weekly exercise amount was lower compared to the level of knowledge. This result suggests that the motivation of individuals for the struggle against obesity is lower than expected, there may be some deficiencies in their knowledge level which may not be sufficient enough to establish a cause-effect relationship, and there may be a lack of encouragement and education.

BMI is widely used in the measurement of obesity, and in various epidemiological studies, the correlation of waist / hip ratio and waist circumference with abdominal fat amount has been shown, and for determining cardiovascular risk waist circumference measurement $>94 \mathrm{~cm}$ in men and $>88 \mathrm{~cm}$ in women has been defined as abdominal obesity (Tam \& Çakır, 2012). In our study, the most significant increase in the level of knowledge before and after the training was for our question about the diagnosis and measurement of obesity. Obesity is associated with cardiovascular diseases such as hypertension, cardiomyopathy, left heart failure, and atrial fibrillation (Abdelaal et al., 2017; Kalan \& Yeşil, 2010) and is the most critical component of the metabolic syndrome (Engin, 2017; Furukawa et al., 2017; Kalan \& Yeşil, 2010). In our study, more than half of the participants had comorbid disease; particularly diabetes and hypertension and almost all of the patients with the disease were receiving medical treatment. Accordingly, the participants had the highest rate of correct answers to the question about the association between obesity and hypertension in the pre-test.

Many gastrointestinal and liver diseases can result from obesity. Apart from malignancies, nonalcoholic fatty liver, reflux esophagitis and gallstones are the most common conditions (Cortes et al., 2020; Su et al., 2018). While the participants were able to establish the relationship between high rates of obesity and fatty liver before the training, the rate of those who knew the association with gallstones was found low. Cancer is a disease that is increasing in prevalance and advances rapidly in both diagnosis and treatment, screenings are becoming more common and information can be easily obtained through the media. Obesity is also a risk factor in premenopausal and postmenopausal breast cancer by increasing adipose tissue inflammation and the activity of aromatase and mortality increases by shortening the expected life span as a result of relapses (Abdelaal et al., 2017; Kabat et al., 2017; Moley \& Colditz, 2016). One of the most striking results in our study was the lowest rate of correct answers to the question about the relationship between obesity and breast cancer, and this finding is supported by other studies (Ayar, 2009; Coulson et al. 2006). Menstrual cycle disorders are more common in obese women (Mustageem et al., 2015; Temür et al., 2017). The incidence of anovulation, polycystic ovary syndrome and infertility increases with the presence of obesity 
(Kalan \& Yeşil, 2010; Marzouk \& Ahmed, 2015; Moley \& Colditz, 2016). In our study, the rate of those who knew that fertility decreases with obesity was low in the pre-test. Obesity also increases the risk of multiple myeloma, non-Hodgkin lymphoma, colon, kidney, liver, thyroid, ovarian, cervix, gallbladder, esophagus, pancreas and prostate cancers (Kalan \& Yeşil, 2010; Moley \& Colditz, 2016). The significant increase in the level of knowledge on the relationship between cancer and obesity in the post-test has also shown that training has successfully achieved its purpose in terms of increasing awareness that obesity is a serious disease with complications.

Obstructive Sleep Apnea Syndrome (OSAS) is a disorder that is characterized by recurrent complete or partial obstruction of the upper airways, desaturation attacks and recurrent awakenings during sleep. It is manifested by excessive daytime sleepiness, stopping of breathing and snoring during sleep. The incidence of OSAS is directly proportional to obesity incidence, and it was shown that obesity can cause an increase of up to 10 times (Ayyldiz et al, 2016; Chen et al., 2016). Almost half of the participants answered that difficulties in breathing and snoring during sleep can increase with obesity. There is strong association between obesity and knee osteoarthritis (Güven et al., 2016; Misra et al., 2019). In addition, there are studies showing that weight loss results in decrease in pain, increase in mobility and quality of life (Chu et al. 2018) and obesity was shown to increase knee joint osteoarthritis by increasing acid concentration and inflammation (Senol et al., 2019). This association was one of the questions that the participants answered highly correctly before the training.

Another theme that showed that the training had a significant effect on the knowledge level of the participants was the relationship between depression and obesity. In their study examining the relationship between depression and obesity in adults aged 18-65, Çakmur and Güneş found that the risk of depression was 2.9 times higher in obese and 3.1 times higher in obese women (Çakmur \& Güneş, 2018). In a study conducted with different ethnic groups and genders, a positive association was found between depression and obesity in black obese women (Assari, 2014). There are studies that showing a negative correlation between cognitive functioning such as concentration and memory and obesity (Alam et al., 2019; Cook et al., 2017).

In addition to measuring the change in knowledge level, some additional questions were asked at the end of the test to determine the effectiveness and satisfaction from the training. Nearly all of the participants stated that the training was beneficial for them, that they decided to make a lifestyle change after the training and that they could apply to the Healthy Life Centers regarding this purpose. More than half of the participants who were satisfied with the training stated that they 
could participate in different training on obesity. This result alone suggests the effectiveness of training in order to raise awareness and to prompt people for action.

Investigating the change of knowledge levels with interactive education; there are some previous studies that detect the change in knowledge level compared before and immediately after training39 or measure the change in knowledge level after a while (Alıc1 \& Pınar, 2008; Doğan et al., 2013; Mbachu et al., 2017). In common, all of these studies reported that interactive education caused a statistically significant increase in knowledge levels. This study is valuable and guiding because there is no other study in our country in which the knowledge levels of the participants were investigated by pre-test and post-test by training a certain population on the definition, frequency, causes, diagnosis, treatment and complications of obesity, particularly explaining the complications of the disease in a cause-effect relationship. In our study, the education given about obesity increased the level of knowledge after education according to the pre-education status of women and the $\mathrm{H} 1$ hypothesis was accepted. In addition, participants who were trained about obesity and its consequences were encouraged to apply by promoting the Healthy Life Centers, thus our study is valuable.

Our study was performed with only the female population living in a single region. One of the limitations of this study is that it was not applied to a wider population in order to measure the effectiveness of training more accurately and to determine the rate of obesity more accurately within the socio-demographic data of the region, and the lack of education for the male population in order to measure the level of knowledge between different sexes. The fact that the study was conducted in one group without a control group is a limitation of this study.

\section{CONCLUSION AND RECOMMENDATIONS}

Education provided by health professionals on obesity was shown to be effective. Health education for prevention and management of obesity in primary care should be one of the fundamental features of the health services. Community-based trainings should be organized especially for primary and secondary prevention, and the fight against obesity should be supported by ensuring that women in the risk group have sufficient knowledge about this condition. It is recommended to conduct experimental studies with control groups, to conduct studies with larger populations and to include men in these studies.

\section{Acknowledgments}

Contributing to the statistical analysis of our research, thanks to Dr. Mikail Özdemir and also to all participants. 


\title{
Conflict of Interest
}

No confict of interest was declared by the authors.

\author{
Author Contribution
}

Working Concept / Design: L.T.D, H.Y.B

Data collection: L.T.D, R.Ö.

Data analysis and interpretation: R.Ö.

\author{
Text draft: L.T.D, H.Y.B, R.Ö.
}

Approval of the final version of the article: L.T.D, H.Y.B, R.Ö.

\section{REFERENCES}

Abdelaal, M., le Roux, C. W., \& Docherty, N. G. (2017). Morbidity and mortality associated with obesity. Ann. Transl. Med, 5(7), 161. https:// doi.org/10.21037/atm.2017.03.107

Alam, I. G., Negara, J. D. K., Zelphira. F., (Ed.) (2020). Effect of Obesity on Cognitive Function: A Comparative Study of Cognitive Level in Normal Weight and Obesity Students at Senior High School in West Java Indonesia. 4th International Conference on Sport Science, Health, and Physical Education (ICSSHPE 2019); Atlantis Press.

Alıcı, M., \& Pınar, R. (2008). Obez hastalara verilen eğitimin etkinliğinin değerlendirilmesi. Hemşirelikte Araştırma Geliştirme Dergisi, 2, 32-47.

Assari, S. (2014). Association between obesity and depression among American Blacks: role of ethnicity and gender. J Racial Ethn Health Disparities, 1(1), 36-44. https:// doi.0rg/10.1007/s40615-014-0007-5

Ayar, K. Normal kilolu, kilolu ve obez bireylerin obezite ve obezite ilişkili hastalıklar hakkındaki bilgi düzeylerinin değerlendirilmesi ve karşılaştırılması. Yayınlanmamış uzmanlık tezi. Uludağ Üniversitesi Tıp Fakültesi. 2009. https://tez.yok.gov.tr/UlusalTezMerkezi/tezSorguSonucYeni.jsp

Ayyıldız, F., Toka, O., Köktürk, O., \& Rakıcıoğlu, N. (2016). Obstrüktif Uyku Apne Sendromu antropometrik ölçümler ve vücut bileşimi ile Ilişkili midir? Beslenme ve Diyet Dergisi, 44(2), 132-143.

Chen, G. P., Qi, J. C., Wang, B. Y., Lin, X., Zhang, W. B., Zhao, Z. M., ... Lin Q. C. (2016). Applicability of visceral adiposity index in predicting metabolic syndrome in adults with obstructive sleep apnea: a cross-sectional study. BMC Pulm Med, 16(1), 37. https:// doi.org/10.1186/s12890-016-0198-0

Chu, l., Lim, A., \& Ng, C. (2018). Effects of meaningful weight loss beyond symptomatic relief in adults with knee osteoarthritis and obesity: a systematic review and meta analysis. Obes. Rev., 19(11), 1597-1607. https:// doi. огg/10.1111/obr.12726.

Cook, R. L., O’Dwyer, N. J., Donges, C. E., Parker, H. M., Cheng, H. L., Steinbeck, K. S., ...O'Connor, H. T. (2017). Relationship between obesity and cognitive function in young women: The food, mood and mind study. Journal of Obesity. https://doi.org/ 10.1155/2017/5923862. 
Cortés, V. A., Barrera, F., \& Nervi, F. (2020). Pathophysiological connections between gallstone disease, insulin resistance, and obesity. Obes. Rev., 21(4), https://doi.org/10.1111/obr.12983.

Coulson, F., Ypinazar, V., \& Margolis, S. (2006). Awareness of risks of overweight among rural Australians. Rural Remote Health., 6(2), 514.

Çakmur, H., \& Güneş, Ü. B. (2018). Poliklinik başvurularında obezite ve depresyon ilişkisinin incelenmesi. Türkiye Aile Hekimliği Dergisi, 22(2), 58-65. https://doi.org/ 10.15511/tahd.18.00258

Çayır, A., Atak, N., \& Köse, S. K. (2011). Beslenme ve diyet kliniğine başvuranlarda obezite durumu ve etkili faktörlerin belirlenmesi. Ankara Üniversitesi Tıp Fakültesi Mecmuası, 64(1), 13-19. https://doi.org/10.1501/ Tipfak_000000779

Doğan, N., Yiğit, R., \& Erdoğan, S. (2013). Annelere doğum öncesinde verilen yenidoğan bakımı ile ilgili eğitimin doğum öncesi ve doğum sonrasında değerlendirilmesi. Mersin Üniversitesi Sağlık Bilimleri Dergisi, 6(3), 10-8.

Engin, A. (2017). The definition and prevalence of obesity and metabolic syndrome. Obesity and lipotoxicity: Springer, 1-17. https://doi.org/10.1007/978-3-319-48382-5_1.

Furukawa, S., Fujita, T., Shimabukuro, M., Iwaki, M., Yamada, Y., Nakajima, Y.,...Shimomura, I. (2017). Increased oxidative stress in obesity and its impact on metabolic syndrome. J Clin Invest., 114(12), 1752-1761. https://doi. огg/10.1172/JCl21625.

Güven, S. C., Özdemir, O., \& Dinçer, F. (2016). Osteoartrit ve obezite ilişkisi. Turk J Phys Med Rehabil., 19(1), 76-84.

Kabat, G. C., Kim, M. Y., Lee, J. S., Ho, G. Y., Going S. B., Beebe- Dimmer J., ....Rohan, T. E. (2017). Metabolic obesity phenotypes and risk of breast cancer in postmenopausal women. Cancer Epidemiol. Biomarkers Prev., 26(12), 1730-1735. https://doi.org/10.1158/1055-9965.EPI-17-0495.

Kalan, l., \& Yeşil, Y. (2010). Obezite ile ilişkili kronik hastalıklar. Diyabet ve obezite, 78. http://e-kutuphane.teb.org. tr/pdf/mised/mised_may10/14.pdf.

Latner, J. D., Barile, J. P., Durso, L.E., \& O'Brien, K. S. (2014). Weight and health-related quality of life: The moderating role of weight discrimination and internalized weight bias. Eat. Behav., 15, 586-590. https://doi.org/10.1016/j. eatbeh.2014.08.014.

Marzouk, T. M., \& Ahmed, W. A. S. (2015). Effect of dietary weight loss on menstrual regularity in obese young adult women with polycystic ovary syndrome. J. Pediatr. Adolesc. Gynecol., 28(6), 457-461. https://doi.org/10.1016/j. jpag.2015.01.002

Maskarinec, G., Takata, Y., Pagano, I., Carlin, L., Goodman, M.T., Marchand L. L., Nomura A. M. Y.,...Kolonel L. N. (2006). Trends and dietary determinants of overweight and obesity in a multiethnic population. Obesity, 14(4), 717-726. https://doi.org/10.1038/oby.2006.82

Mbachu, C., Dim, C., \& Ezeoke, U. (2017). Effects of peer health education on perception and practice of screening for cervical cancer among urban residential women in south-east Nigeria: a before and after study. BMC Women's Health, 17(1), 41. https://doi.org/10.1186/s12905-017-0399-6

Misra, D., Fielding, R.A., Felson, D.T., Niu, J., Brown, C., Nevitt, M....Neogi, T. (2019). Risk of knee osteoarthritis with obesity, sarcopenic obesity, and sarcopenia. Arthritis Rheumatol., 71(2), 232-237. https://doi.org/10.1002/ art.40692

Moley, K. H., \& Colditz, G.A. (2016). Effects of obesity on hormonally driven cancer in women. Sci. Transl. Med., 8, 323. https://doi.org/10.1126/scitranslmed.aad8842 
Mustaqeem, M., Sadullah, S., Waqar, W., Farooq, M., Khan, A., \& Fraz, T. (2015). Obesity with irregular menstrual cycle in young girls. Mymensingh Med J., 24(1), 161-167.

O'Brien, K. S., Latner, J. D., Puhl, R. M., Vartanian, L. R., Giles, C., Griva, K., \& Carter, A. (2016). The relationship between weight stigma and eating behavior is explained by weight bias internalization and psychological distress. Appetite, 102, 70-76. https://doi.org/10.1016/j.appet.2016.02.032.

Redmon, J. B., Reck, K. P., Raatz, S. K., Swanson J. E., Kwong C. A., Ji, H., ...Bantle, J. P. (2005). Two-year outcome of a combination of weight loss therapies for type 2 diabetes. Diabetes Care, 28, 1311-1315.

Senol, O., Gundogdu, G., Gundogdu, K., \& Miloglu, F. D. (2019). Investigation of the relationships between knee osteoarthritis and obesity via untargeted metabolomics analysis. Clin. Rheumatol.,38(5), 1351-1360. https:// doi.org/10.1007/s10067-019-04428-1

Sertöz, Ö. Ö., \& Mete, H. E. (2005). Obezite tedavisinde bilişsel davranışçı grup terapisinin kilo verme, yaşam kalitesi ve psikopatolojiye etkileri: Sekiz haftalık izlem çalışması. Klinik Psikofarmakoloji Bülteni, 15, 119-126.

Su, P. Y., Hsu, Y. C., Cheng, Y. F., Kor, C. T., \& Su, W. W. (2019). Strong association between metabolically-abnormal obesity and gallstone disease in adults under 50 years. BMC Gastroenterology, 19(1), 117. https://doi. org/10.1186/s12876-019-1032-y.

Tam, A. B., \& Çakır, B. (2012). Birinci basamakta obeziteye yaklaşım. Ankara Medical Journal, 12(1), 37-41.

T. C. Sağlık Bakanlığı Temel Sağlık Hizmetleri Genel Müdürlüğü. Türkiye Obezite Ille Mücadele ve Kontrol Programı 2010-2014. Birinci baskı, 30-32.

Tedik, S.E. (2017). Fazla Kilo/Obezitenin Önlenmesinde ve Sağlıklı Yaşamın Desteklenmesinde Hemşirenin Rolü. Turk J Diab Obes., 2, 54-62. . https://doi.0rg/10.25048/tjdo.2017.9

Temür, M., Çift, T., Balcı, U. G., Güçlü, Y. A., Yılmaz, Ö., \& Öngel, K. (2017). Kadın yaşamında obezitenin jinekolojik etkileri. SDÜ Tıp Fakültesi Dergisi, 24(4), 153-158. https://doi.org/10.17343/sdutfd.302057

Türkiye Endokrinoloji ve Metabolizma Derneği (2014). Obezite Tanı ve Tedavi Kılavuzu 5.Baskı. Ankara, 11-16.

Ulusal Hastalık Yükü Çalışması (2017). Hacettepe Üniversitesi Tıp Fakültesi. http://www.tip.hacettepe.edu.tr/ekler/ pdf/ulusal_program.pdf.

Ural, D., Kılıçkap, M., Göksülük, H., Karaaslan, D., Kayıkçıŏlu, M., Özer, N.,..Tokgözoğlu, L. (2018). Türkiye’de obezite sıkığı ve bel çevresi verileri: Kardiyovasküler risk faktörlerine yönelik epidemiyolojik çalışmaların sistematik derleme, meta-analiz ve meta-regresyonu. Turk Kardiyol Dern Ars., 46(7), 577-590. https://doi.org/10.5543/ tkda.2018.62200

Uzuntarla, Y. (2016). Genç yaş grubunun organ bağışına yönelik düşünce ve bilgi düzeylerinin verilen eğitime göre karşılaştırılması. Türk Nefroloji Diyaliz ve Transplantasyon Dergisi, 25(3), 296-301.

WHO. Global Health Observatory (GHO) data. https://www.who.int/gho/ncd/risk_factors/overweight_text/en/ Accessed December 19, 2020.

Womble, L. G., Wadden, T., McGuckin, B.G., Sargent, S. L., Rothman, R. A., \& Krauthamer-Ewing E. S. (2004). A randomized controlled trial of commercial internet weight loss program. Obes Res., 12, 1011-1018. https:// doi.org/10.1038/oby.2004.124 